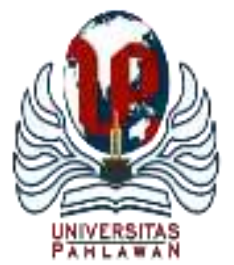

Edukatif : Jurnal Ilmu Pendidikan Volume 3 Nomor 5 Tahun 2021 Halm 3376 - 3384

EDUKATIF: JURNAL ILMU PENDIDIKAN

Research \& Learning in Education

https://edukatif.org/index.php/edukatif/index

\title{
Aplikasi Microsoft Excel dalam Pembelajaran Matematika Materi Bangun Ruang
}

\author{
Didin Adri ${ }^{1 凶}$, La Ode Muhamad Ramadhan² \\ Universitas Muhammadiyah Buton, Baubau, Indonesia ${ }^{1,2}$ \\ E-mail : adri.didin@gmail.com ${ }^{1}, \underline{\text { ramadhan.laode@gmail.com }}^{2}$
}

\begin{abstract}
Abstrak
Penerapan aplikasi komputer mempunyai potensi besar untuk meningkatkan kualitas pembelajaran khususnya pembelajaran matematika. Salah satu aplikasi yang digunakan untuk media pembelajaran adalah MS-Excel. MS-Excel sangat membantu dalam menvisualisasikan gambar atau grafik sehingga pembelajaran akan nampak lebih menarik, sehingga diharapkan dalam menarik pandangan siswa untuk melihat dan belajar matematika khususnya pada siswa tingkat dasar (SD). Pada penelitian ini akan diuraikan sebuah aplikasi yang dibuat dengan menggunakan MS-Excel untuk menganalisis sifat-sifat bangun ruang dan menghitung volume dan luas permukaan bangun ruang serta menvisualisasikan gambar bangun ruang yang dinamis. Aplikasi pembelajran matematika dalam penelitian ini dapat dijadikan pedoman bagi praktisi dan guru, dalam mengembangkan media pembelajaran matematika sesuai dengan karakteristik pembelajaran matematika yang diterapkan, baik dari segi tahapan pengembangan maupun proses untuk mendapatkan media pembelajaran yang berkualitas yang baik.

Kata Kunci : Pembelajaran Matematika SD, Microsof Excel, Bangun Ruang.
\end{abstract}

\section{Abstract}

The application of computer program has great potential to improve the quality of learning, especially mathematics learning. One of the applications used for learning media is MS-Excel. MS-Excel is very helpful in visualizing images or graphics so that learning will look more interesting, so it is hoped that it will attract students' mind to see and learn mathematics, especially for elementary level students. In this study, an application created using MS-Excel will be described to analyze the properties of the spatial structure and calculate the volume and surface area of the building as well as visualize dynamic spatial images. The application of mathematics learning in this study can be used as a guide for practitioners and teachers, in developing mathematics learning media in accordance with the characteristics of applied mathematics learning, both in terms of the stages of development and the process to obtain good quality learning media Keywords: Primary Mathematics learning, Microsoft Excel, geometry.

Copyright (c) 2021 Didin Adri, La Ode Muhamad Ramadhan

$\triangle$ Corresponding author

Email : adri.didin@gmail.com

DOI : https://doi.org/10.31004/edukatif.v3i5.922

ISSN 2656-8063 (Media Cetak)

ISSN 2656-8071 (Media Online) 


\section{PENDAHULUAN}

Pada zaman digital dan teknologi sekarang ini penerapan aplikasi komputer mempunyai potensi besar untuk meningkatkan kualitas pembelajaran khususnya pembelajaran matematika. Dalam matematika banyak hal yang abstrak yang sulit dibayangkan siswa, hal ini dapat disimulasikan melalui aplikasi komputer. Melalui Aplikasi tersebut, dapat dijadikan sebagai alat bantu guru untuk menyiapkan materi dalam pembelajaran. Contohnya media pembelajaran dengan menggunakan MS - EXCEL (Jazi Eko Istiyanto, 2013).

Microsoft Excel adalah sebuah program aplikasi lembar kerja spreadsheet yang populer dan paling sering digunakan di setiap PC. Saat ini, aplikasi MS-EXCEL merupakan program spreadsheet paling banyak digunakan oleh banyak pihak. MS-Excel sangat membantu dalam menghitung, Menvisualisaikan grafik atau gambar dan mempresentasikan data dalam bentuk tabel dengan berbagai jenis tabel yang disediakannya, sehingga MS-EXCEL bisa dijadikan salah satu alternatif solusi untuk pembelajaran Matematika Bangun Ruang.(Munir, 2012; Euis Eti Rohaeti, 2018; Arifin, 2019).

Tujuan dari penelitian ini adalah untuk membuat aplikasi pembelajaran Matematika materi bangun ruang dengan menggunakan software Microsoft Excel. Aplikasi ini dapat diakses melalui media smartphone, tablet, atau juga PC/Laptop. Manfaat dari kajian ini adalah diharapkan aplikasi pembelajaran ini dapat menyederhanakan perhitungan volume dan luar permukaan bangun ruang dan menvisualisasikan gambar ruang secara dinamis sehingga memudahkan guru dalam menyusun media pembelajaran dan pemahaman siswa dalam mempelajari materi bangun ruang akan menjadu lebih baik.(Arsyad and Azhar, 2011)

Microsoft Excel (Ms. Excel) merupakan salah satu program dari keluarga Microsoft Office yang berbasis pada sistem operasi Windows. Ms. Excel berfungsi untuk memproses data berupa angka atau bilangan dengan menggunakan spreadsheet yang terdiri dari baris dan kolom. Ms. Excel telah menjadi aplikasi pemroses data dan angka yang paling umum digunakan, dan dapat digunakan pada berbagai media seperti PC, tablet, atau smartphone. Microsoft Excel tidak hanya tersedia dalam platform Windows, tetapi juga tersedia pada sistem operasi MacOS, Android dan Apple IOS. Ms. Excel menggunakan spreadsheet untuk menjalankan berbagai formula. Spreadsheet adalah kumpulan dari cell yang terdiri atas baris dan kolom sebagai tempat dimana angka dan data diolah.(Nazruddin Safaat H., 2015).

Pada penelitian ini materi bangun ruang dikhususkan untuk bangun ruang Balok, kubus dan Limas yakni sebagai berikut :

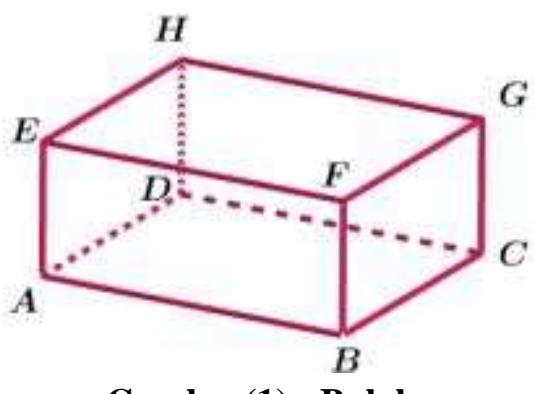

Gambar(1) : Balok

Balok merupakan bangun ruang yang dibatasi oleh tiga pasang sisi sejajar yang berbentuk persegi atau persegi panjang dengan setidaknya terdapat satu pasang sisi sejajar yang memiliki ukuran yang berbeda. Balok memiliki ciri-ciri yaitu: 1)Mempunyai 6 sisi, sisi yang berhadapan memiliki bentuk dan ukuran yang sama; 2) Mempunyai 8 titik sudut; 3) Mempunyai 12 rusuk.(Depdiknas, 2008).

Volume Balok dapat dihitung dengan menggunakan rumus $\mathrm{V}=\mathrm{P} \times \mathrm{L} \times \mathrm{T}$.Sedangkan Luas permukaan Balok dapat dihitung dengan menggunakan rumus $\mathrm{L}=2 \times(\mathrm{P}+\mathrm{L}+\mathrm{T})$. Dalam hal ini, panjang disimbolkan 
dengan huruf $\mathrm{P}$, lebar disimbolkan dengan huruf $\mathrm{L}$ dan tinggi disimbolkan dengan huruf T.(Sri Hastuti Noer, 2019; Rostina Sundayana, 2020)

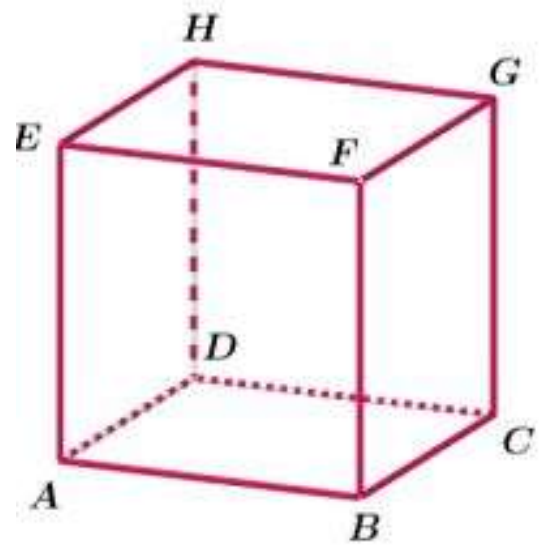

Gambar(2) : Kubus

Kubus adalah bangun ruang yang dibatasi oleh enam sisi yang berbentuk persegi. Kubus memiliki ciriciri yaitu, 1) Kubus mempunyai enam sisi yang berukuran sama (kongruen), mempunyai delapan titik sudut, dan dua belas rusuk yang sama panjang; 2) Kubus di atas dapat kita beri nama sebagai kubus ABCD.EFGH. Selanjutnya kita akan belajar mengenai beberapa contoh penerapan kubus.

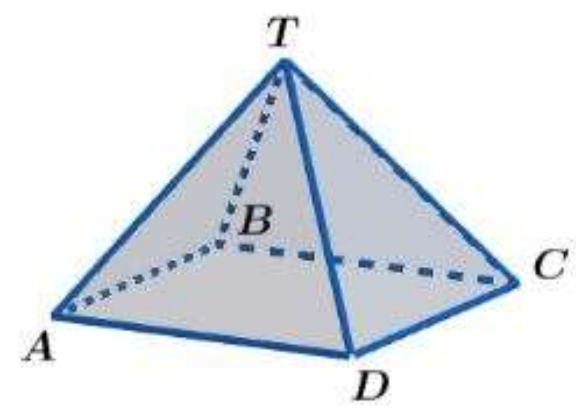

\section{Gambar(3) : Limas segi empat}

Secara umum, limas dapat diartikan sebagai salah satu bangun ruang sisi datar yang dibatasi oleh sebuah sisi alas yang berupa segibanyak dan sisi-sisi tegak yang berbentuk segitiga, salah satu titik sudut dari masing-masing segitiga tersebut bertemu pada satu titik yaitu titik puncak limas. Pemberian nama pada limas berdasarkan pada bentuk alasnya. Suatu limas yang alasnya berbentuk segitiga disebut dengan limas segitiga, limas dengan sisi alas berbentuk segi empat diberi nama limas segi empat, dan begitu pula dengan sisi alas yang berbentuk segibanyak lainnya. Volume Balok dapat dihitung dengan menggunakan rumus $\mathrm{V}=1 / 3 \times \mathrm{La}$ $\times$ t. Sedangkan Luas permukaan Balok dapat dihitung dengan menggunakan rumus $L=(a \times a)+(2 \times a \times t)$. Dalam hal ini, Luas Alas disimbolkan dengan La, panjang sisi alas disimbolkan dengan huruf a dan tinggi disimbolkan dengan huruf $t$.

\section{METODE PENELITIAN}

Metode yang digunakan dalam penelitian ini menggunakan pendekatan penelitian pengembangan (Research and Development). Metode penelitian dan pengembangan adalah metode penelitian yang digunakan 
untuk menghasilkan produk tertentu dan untuk dapat menghasilkan produk tersebut digunakan penelitian yang bersifat analisis kebutuhan.

Berikut ini gambar diagram metode penelitian yang dibuat untuk mempermudah dalam pembuatan dalam media pembelajaran matematika.

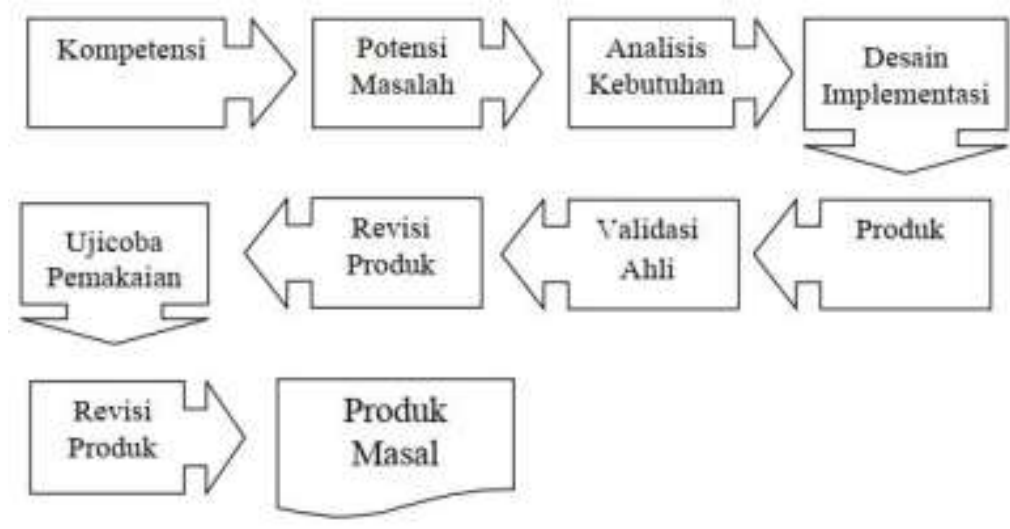

Gambar(4) : Limas segi empat Langkah-langkah penggunaan Metode Research and Development (Adaptasi dari Sugiyono, 2008: 298)

Penelitian penerapan microsoft excel dalam pembelajaran matematika materi bangun ruang dilakukan di Laboratorium Komputer Universitas Muhammadiyah Buton. Kemudian Penelitian ini dilaksanakan pada tahun ajaran 2019/2020 semester genap yaitu pada bulan Februari-Mei 2020. Subjek dalam penelitian ini adalah siswa Kelas IV SD Negeri 2 Lamangga yang berjumlah 24 siswa.

Instrumen yang digunakan dalam penelitian ini ditujukan untuk menilai kelayakan Microsoft Excel dalam pembelajaran matematika materi bangun ruang. Data yang diperoleh dari angket ini adalah data kuantitatif. Bentuk angket yang digunakan adalah skala bertingkat yaitu sebuah pertanyaan diikuti oleh kolom-kolom yang menunjukkan tingkatan-tingkatan (Agus Buchori, 2011).

Sebelum Instrumen digunakan dalam penelitian, maka instrumen harus diuji cobakan terlebih dahulu. Hal tersebut dilakukan guna bertujuan untuk memperoleh informasi mengenai sudah atau belum terpenuhinya persyaratan. Instrumen memunuhi syarat sebagai alat pengumpulan data yang valid dan reliabel. Pengujian dilakukan di SD Negeri 2 Lamangga dengan subjek yang digunakan untuk uji coba adalah siswa kelas IV sebanyak 10 siswa.

Teknik pengumpulan data pada penelitian ini menggunakan observasi dan dokumentasi, dengan tujuan untuk menentukan Microsoft Excel dalam pembelajaran matematika materi bangun ruang. Observasi dilaksanakan pada saat uji ahli media pembelajaran, uji ahli materi dan uji coba produk, sedangkan teknik pengumpulan data dengan dokumentasi digunakan saat uji coba pemakaian produk.

\section{HASIL DAN PEMBAHASAN PENELITIAN}

\section{Tahap Pembuatan Media Menggunakan Excel}

Pengembangan Aplikasi Excel dalam penelitian ini adalah membuat Grafik 3D di Excel, membuat form input untuk nilai-nilai yang diketahui dalam permasalahan, membuat tampilan hasil perhitungan untuk Volume dan Luas permukaan dan Desain tampilan aplikasi agar nampak lebih menarik.

Membuat Grafik 3D di Excel. Pada tahapan ini, akan dibuat gambar bangun ruang yang dinamis yang ukurannya menyesuai dengan inputan yang diketahui misalnya panjang, lebar dan tinggi. Gambar bangun 
3380 Aplikasi Microsoft Excel dalam Pembelajaran Matematika Materi Bangun Ruang - Didin Adri, La Ode Muhamad Ramadhan

DOI: https://doi.org/10.31004/edukatif.v3i5.922

ruang digambar dengan cara mengubah koodinat 3D-xyz menjadi koordinat 2D-x'y' Mengikuti persamaan sebagai berikut

$$
\begin{aligned}
& \boldsymbol{x}^{\prime}=(-0.35 \cdot x)+y \\
& \boldsymbol{y}^{\prime}=(-0.35 \cdot x)+z
\end{aligned}
$$

Kemudian dari persamaan ini, dibuatkan grafik dengan menuliskan nilai-nilai pada cells excel, kemudian membuat grafik tipe scartter with straight line and markekrs pada tab insert - chart scartter $x-y$ seperti nampak pada gambar berikut:
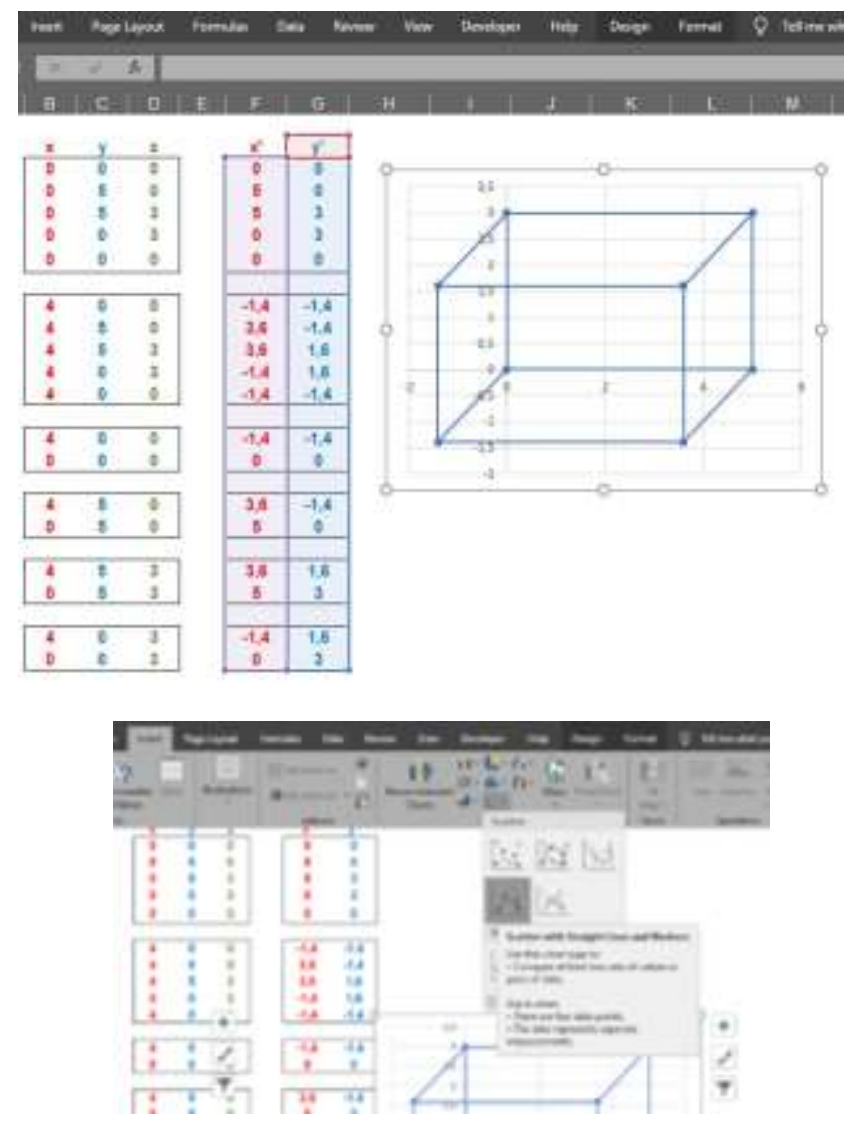

Gambar (5) : Penerapan Rumus (1)

Membuat Input Untuk Nilai Yang Diketahui. Pada tahapan ini, nilai cell pada kolom $x, y$, dan $z$ akan buat menjadi otomatis terhitung berdasarkan pada nilai yang diketahui, dalam hal ini panjang, luas dan tinggi balok Seperti nampak pada gambar (6). Kemudian membuat tombol spin untuk mengubah nilai inputan panjang, lebar dan tinggi pada tab Devoloper dengan memilih spin button seperi nampak pada gambar (7). 


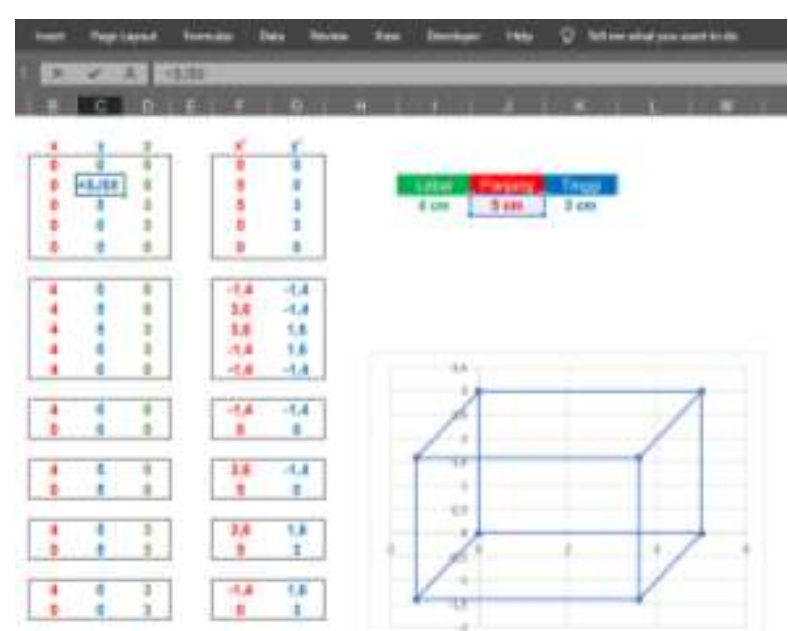

Gambar (6) : Membuat inputan nilai panjang, lebar dan tinggi
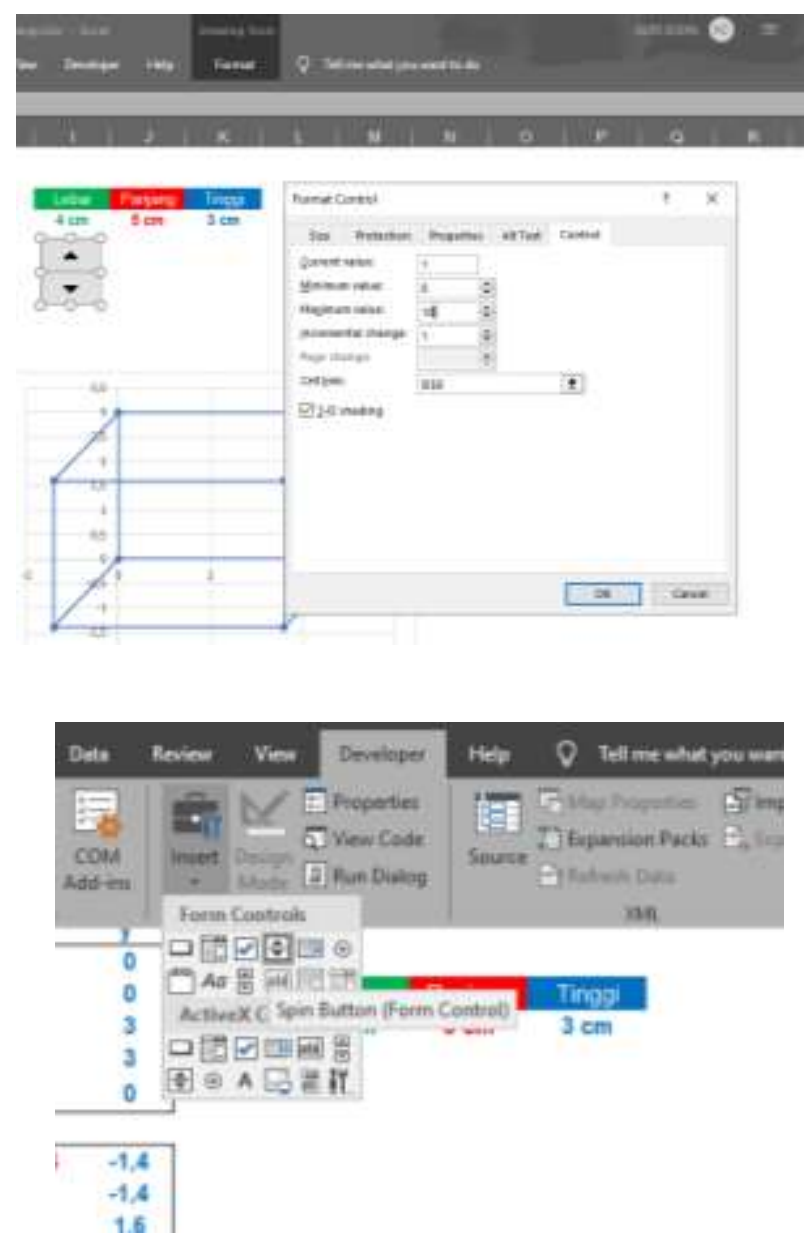

Gambar (7) : Membuat inputan nilai panjang, lebar dan tinggi

Membuat tampilan hasil Volume dan Luas permukaan. Pada tahapan ini, akan dihitung nilai Volume dan Balok secara otomatis terdasarkan pada inputan nilai panjang, lebar dan tinggi dengan menerapkan rumus pada subbagian 2.2.1. Seperti nampak pada gambar (8) berikut: 


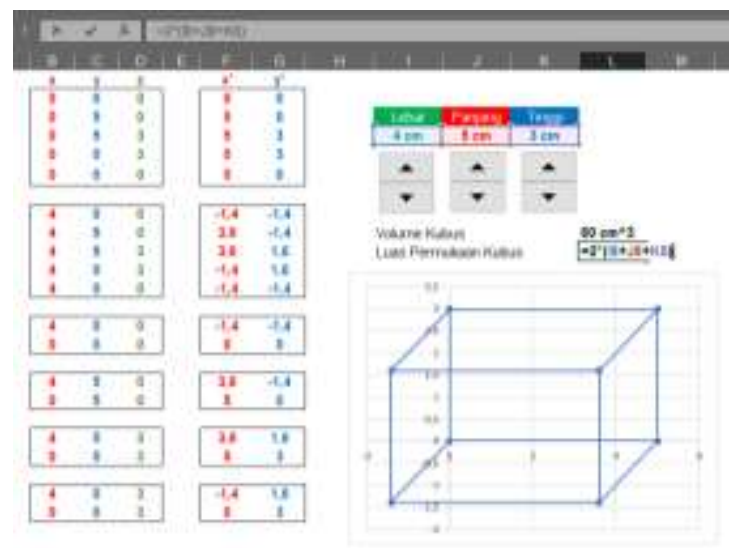

\section{Gambar (8)}

Tampilan Aplikasi, Aplikasi ini dapat dijalankan pada PC dengan operating system windows yang terinstal program MS. Excel Versi 2017 atau versi diatas 2017 dan pada Tablet dan Smartphone dengan operating system Android yang terinstal aplikasi pembacara document tipe excel.

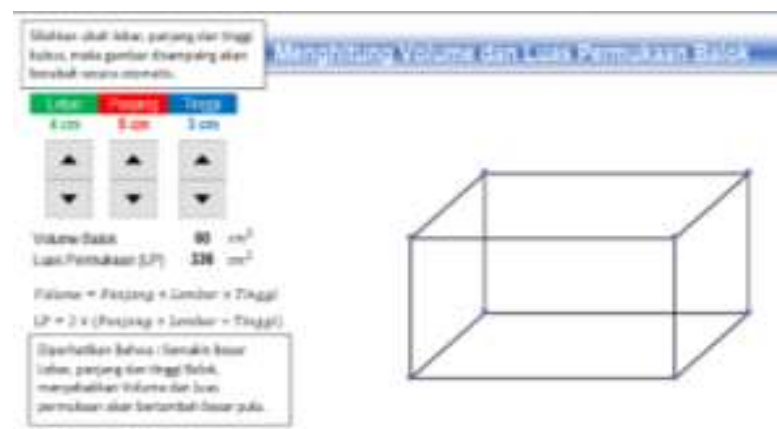

Gambar (9)

Cara menggunakan aplikasi ini cukup dengan memasukan nilai Panjang, lebar dan kolom pada tombol spin maka secara otomatis nilai volume dan luas perkukaan balok akan tampil, selain itu gambar balok akan berubah sesuai dengan inputan yang dimusukan. Selanjutnya dengan cara yang sama, aplikasi ini sudah kembangkan untuk menghitung Volume dan luas permukaan Limas, seperti nampak pada gambar (10).

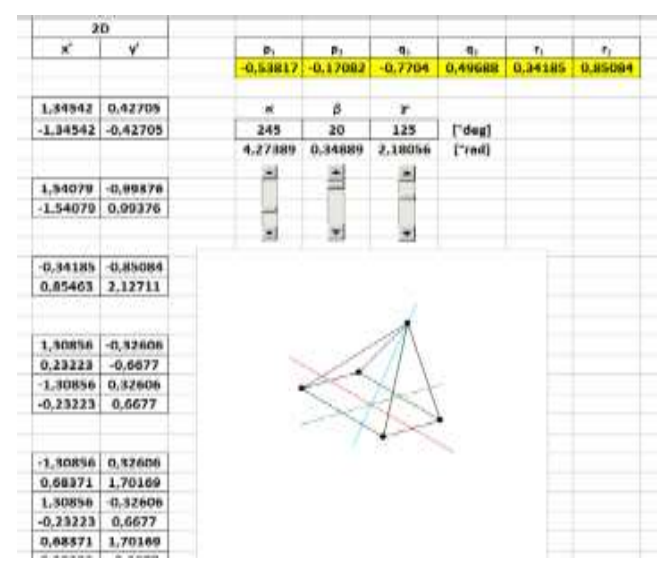

Gambar (10)

Edukatif : Jurnal Ilmu Pendidikan Vol 3 No 5 Tahun 2021 p-ISSN 2656-8063 e-ISSN 2656-8071 


\section{Pembahasan Analisis Instrumen}

Hasil pengujian validitas instrumen ini dengan cara mencari korelasi product moment dari masingmasing item instrumen kemudian diinteprestasikan dengan ( $\mathrm{r}$ ) table dengan $\mathrm{n}=10$ sebesar 0,335 , dengan hasil bahwa semua item/butir soal dalam instrumen itu valid. Pada penelitian ini peneliti menggunakan validitas logis yaitu instrumen itu dikonsultasikan kepada ahli atau dosen yang berkompeten. Data ujicoba dilakukan pada 12 April 2020.

Pengujian reliabilitas instrumen memperoleh nilai Alpha sebesar 0,7852650, nilai Alpha >0,456 dengan $n=10$ pada table $r$ product moment mengindikasikan instrumen pada penelitian ini reliable. Data uji coba dilakukan pada 12 April 2020.

Berdasarkan data validasi ahli materi dan ahli serta uji coba lapangan, maka media pembelajaran matematika dengan menerapkan Excel yang dibuat ini layak digunakan dan dimanfaatkan sebagai salah satu suplemen pembelajaran terutama pada masa pembelajaran online. Disamping itu menggunakan media pembelajaran mateamtika dengan Microsoft Excel menjadi lebih efektif. Materi yang dibuat juga sudah sesuai dengan standar kompetensi dan kompetensi dasar.

Dari penelitian yang telah dilakukan maka dapat disimpulkan bahwa Microsoft Excel dapat digunakan sebagai aplikasi Matematika untuk menghitung volume dan luas permukaan balok dan Limas. Aplikasi ini dapat digunakan oleh berbagai kalangan sebagai media pembelajaran matematika bangun ruang secara cepat, tepat, dan akurat. Pada Penelitian ini, telah dihitung untuk menghitung Volume dan luas permukaan bangun ruang Kubus, balok dan prisma, Selanjutnya Aplikasi ini bisa dikembangkan untuk menghitung bangun bangun yang lain. Seperti Kubus, Limas segi-n, Prisma, bola dan lain-lain.Click or tap here to enter text.

\section{UCAPAN TERIMA KASIH}

Terimakasih kepada Rektor Universitas Muhammadiyah Buton yang sudah membantu peneliti dalam penerbitan artikel ini. Kepada pihak penerbit yang sudah bersedia memeriksa artikel dan menerbitkan artikel ini. Terimakasih kepada banyak pihak yang sudah berkontribusi atas penyelesaian penelitian ini sampai menjadi artikel penelitian.

\section{DAFTAR RUJUKAN}

Agus Buchori (2011) Media Pembelajaran Microsoft Excel Berbasis Multimedia Di Sma Negeri 1 Ngemplak. Yogyakarta.

Arifin, J. (2019) Mengusai Microsoft Excel 2019. Jakarta: Elex Media Komputindo.

Arikunto, S. (2008) Dasar-Dasar Evaluasi Pendidikan. Jakarta: Pt Bumi Aksara.

Arsyad And Azhar (2011) Media Pembelajaran. Jakarta: Pt. Rajagrafindo Persada.

Daryanto (2010) Media Pembelajaran Perananya Sangat Penting Dalam Mencapai Tujuan Pembelajaran. Yogyakarta: Gava Media.

Denny Setiawan (2017) Pengembangan Bahan Ajar. Tangerang: Universitas Terbuka.

Depdiknas (2008) Panduan Pengembangan Bahan Ajar. Jakarta: Direktorat Pembinaan Sma.

Euis Eti Rohaeti (2018) Media Pembelajaran Matematika Berbasis Ict Dgn Vba Microsoft Excel. Bandung: Refika.

Jazi Eko Istiyanto (2013) Pemrograman Smart Phone Menggunakan Sdk Android Dan Hacking Android. Yogyakarta: Media Kom.

Matej Pašák (2018) How To Create 3d Charts And Xyz Coordinates In Excel, Www.Maclab.Sk. 
3384 Aplikasi Microsoft Excel dalam Pembelajaran Matematika Materi Bangun Ruang - Didin Adri, La Ode Muhamad Ramadhan

DOI: https://doi.org/10.31004/edukatif.v3i5.922

Munir (2012) Multimedia Konsep Dan Aplikasi Dalam Pendidikan. Bandung: Alfabeta.

Nazruddin Safaat H. (2015) Pemograman Aplikasi Mobile Smartphone Dan Tablet Pc Berbasis Android. Bandung: Informatika Bandung.

Redja Mudyaharjo (2002) Pengantar Pendidikan. 2nd Edn. Jakarta: Pt. Rajagrafindo Persada.

Richard, E. M. (2001) Multimedia Learning Prinsip-Prinsip Dan Aplikasi. Yogyakarta: Pustaka Pelajar.

Rostina Sundayana (2020) Media \& Alat Peraga Dalam Pembelajaran Matematika. Bandung: Alfabeta.

Sadiman, A. S. (2010) Media Pendidikan: Pengertian, Pengembangan, Dan Pemanfaatannya, Arief S. Sadiman. Jakarta.

Sri Hastuti Noer (2019) Desain Pembelajaran Matematika; Untuk Mahasiswa Program Studi Pendidikan Matematika. 2nd Edn. Jakarta: Graha Ilmu.

Sugiyono (2014) Metode Penelitian Pendidikan (Pendekatan Kuantitatif, Kualitatif Dan R\&D). Bandung: Alfabeta.

Suyatman (2013) Pengembangan Bahan Ajar. Surakarta: Fataba Press Iain Surakarta.

Yuliani H. R. (2020) Matematika Berbasis Ms Excel. Yogyakarta: Deepublish. 